\title{
Candida albicans-The Virulence Factors and Clinical Manifestations of Infection
}

\author{
Jasminka Talapko ${ }^{1}$ (D), Martina Juzbašić ${ }^{1}$, Tatjana Matijević ${ }^{2}$, Emina Pustijanac ${ }^{3}$, Sanja Bekić ${ }^{4,5}$, Ivan Kotris ${ }^{6}$ \\ and Ivana Škrlec 1 ,*iD \\ 1 Faculty of Dental Medicine and Health, Josip Juraj Strossmayer University of Osijek, \\ HR-31000 Osijek, Croatia; jtalapko@fdmz.hr (J.T.); martina.juzbasic@fdmz.hr (M.J.) \\ 2 Department of Dermatology and Venereology, Clinical Hospital Center Osijek, HR-31000 Osijek, Croatia; \\ tatjana.7.kovacevic@gmail.com \\ 3 Faculty of Natural Sciences, Juraj Dobrila University of Pula, HR-52100 Pula, Croatia; \\ emina.pustijanac@unipu.hr \\ 4 Family Medicine Practice, HR-31000 Osijek, Croatia; sbekic@mefos.hr \\ 5 Faculty of Medicine, Josip Juraj Strossmayer University of Osijek, HR-31000 Osijek, Croatia \\ 6 Department of Internal Medicine, General County Hospital Vukovar, HR-3200 Vukovar, Croatia; \\ ikotris@mefos.hr \\ * Correspondence: iskrlec@fdmz.hr
}

check for updates

Citation: Talapko, J.; Juzbašić, M.; Matijević, T.; Pustijanac, E.; Bekić, S.; Kotris, I.; Škrlec, I.

Candida albicans-The Virulence

Factors and Clinical Manifestations of Infection. J. Fungi 2021, 7, 79 https://doi.org/10.3390/jof7020079

Received: 6 January 2021

Accepted: 21 January 2021

Published: 22 January 202

Publisher's Note: MDPI stays neutral with regard to jurisdictional claims in published maps and institutional affiliations.

Copyright: (c) 2021 by the authors. Licensee MDPI, Basel, Switzerland. This article is an open access article distributed under the terms and conditions of the Creative Commons Attribution (CC BY) license (https:// creativecommons.org/licenses/by/ $4.0 /)$.

\begin{abstract}
Candida albicans is a common commensal fungus that colonizes the oropharyngeal cavity, gastrointestinal and vaginal tract, and healthy individuals' skin. In $50 \%$ of the population, C. albicans is part of the normal flora of the microbiota. The various clinical manifestations of Candida species range from localized, superficial mucocutaneous disorders to invasive diseases that involve multiple organ systems and are life-threatening. From systemic and local to hereditary and environmental, diverse factors lead to disturbances in Candida's normal homeostasis, resulting in a transition from normal flora to pathogenic and opportunistic infections. The transition in the pathophysiology of the onset and progression of infection is also influenced by Candida's virulence traits that lead to the development of candidiasis. Oral candidiasis has a wide range of clinical manifestations, divided into primary and secondary candidiasis. The main supply of $C$. albicans in the body is located in the gastrointestinal tract, and the development of infections occurs due to dysbiosis of the residential microbiota, immune dysfunction, and damage to the muco-intestinal barrier. The presence of $C$. albicans in the blood is associated with candidemia-invasive Candida infections. The commensal relationship exists as long as there is a balance between the host immune system and the virulence factors of $C$. albicans. This paper presents the virulence traits of Candida albicans and clinical manifestations of specific candidiasis.
\end{abstract}

Keywords: Candida albicans; virulence traits; oral cavity; gastroenterology; dermatovenerology

\section{Introduction \\ 1.1. Fungal Infection}

Pathogens that causes fungal infections, such as Candida albicans, are widespread and may affect the skin and mucosal surface, and may cause systemic infection. Species of Candida are present in as many as 400,000 systemic fungal diseases [1]. Of all the species, Candida albicans is the most common causative agent of mucosal infections and systemic infection, and it is responsible for about $70 \%$ of fungal infections around the world [2]. It has been the leading cause of life-threatening invasive infections for the past several decades. Despite treatment, the mortality rate is close to $40 \%$, especially in hospital conditions [3,4]. The present review aims to provide an overview of the virulence traits of Candida albicans and its clinical manifestations in the oral cavity, intestinal mucosa, skin, as well as in invasive infections. 


\subsection{Candida Albicans}

Candida albicans appears in several morphological forms (blastospores, pseudohyphae, and hyphae) (Figure 1). Blastospores divide asexually by budding $[5,6]$. During that process, new cell material is formed on the surface of the blastospore. The new bud grows from a small selected blastospore, and it is most often located distally from the site of a scar caused by birth, after which the phase of growth begins. After the growth phase ends, the cells divide, whereby the daughter separates from the parent cell by creating a partition [6].

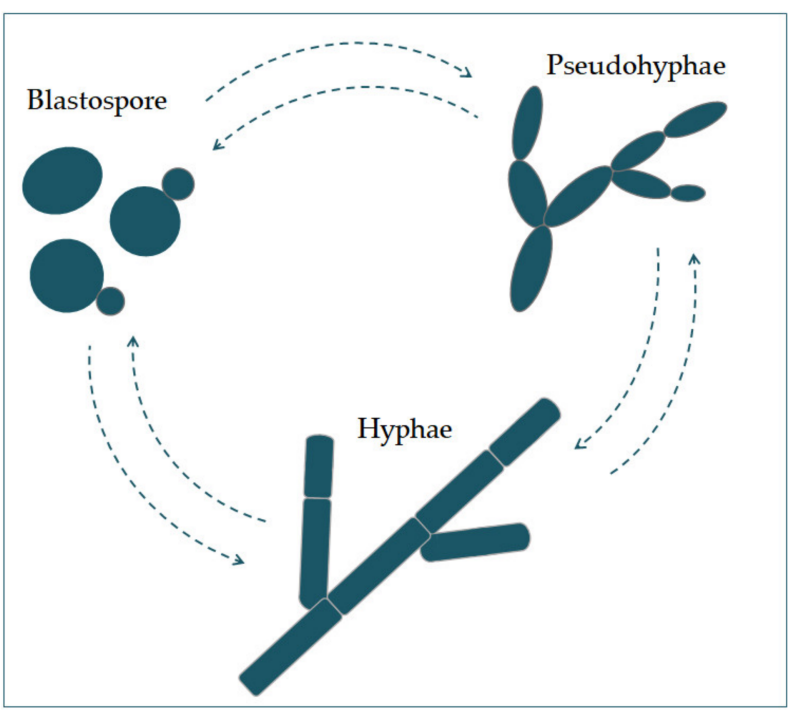

Figure 1. The morphological switches and transitions of Candida albicans during the infection process. The morphological transitions from blastospore to pseudohyphae and hyphae are reversible.

Chains of elongated yeast cells characterize pseudohyphae, and the shape of hyphae is characterized by branched chains of tubular cells, with no narrowing at the sites of septation [7]. Filamentation is enhanced by a temperature higher than $37^{\circ} \mathrm{C}$, an alkali pH, serum, and high concentrations of $\mathrm{CO}_{2}$ [8]. In the same way, it is also enhanced by a lack of nitrogen and carbon in the presence of $\mathrm{N}$-acetylglucosamine (GlcNAc) [7]. This transition from a blastospore to a hypha is characterized by the activation of a complex regulatory network of signal paths, which include many transcription factors [8]. The main difference between yeast and hyphae composition is that the hypha wall has slightly more chitin content than yeast [9].

The cell wall is made of glucan, chitin, and protein. Its role is to protect the cell from stressful conditions in the environment, such as osmotic changes, dehydration, and temperature changes, and protect the cells from the host's immune defense [10,11]. It is also responsible for adhesion to the host cell, with adhesion proteins such as Als1-7, Als9, and Hwp1 [12].

Communication of the cell with the outside environment takes place through the cell membrane [13]. Sterols in the cell membrane are extremely important, giving the cell stability, rigidity, and resistance to physical stressors [9]. Ergosterol is the most represented sterol and is characteristic for the cell membrane of fungi. It is synthesized on the endoplasmic reticulum and lipid bodies [14]. In the cell membrane, there is a phospholipid bilayer containing proteins with the role of receptors, but also some whose role is transport and also signal transduction [15].

In its metabolism, Candida albicans uses glucose as a source of carbon and amino acids as nitrogen sources [16].

\section{Virulence Factors of Candida albicans}

Candida participates actively in the pathophysiology of the occurrence and advance of infection, thanks to its virulence factors. One group of virulence factors causes colonization 
to take place, or the initiation of an infection, whilst the other group helps to spread the infection [17].

Polymorphism implies the transition of $C$. albicans from a commensal form to a pathological one, which depends on changes in the environment in which it is located. It is characterized by the morphological transition of blastospores into hyphae, and the transitional form between are pseudohyphae $[18,19]$. Asexual spores, chlamydospores, are formed under adverse conditions and are three to four times bigger than blastospores [12]. The morphological transition of $C$. albicans begins with the budding of blastospores and the formation of new cells. The nuclei separate at the mother-daughter cell junction via the septum [20]. The nuclei of hyphal forms divide in the germ tube but outside the septum region. After division, one nucleus returns to the mother cell, and the other moves toward the center of the germ tube [21]. C. albicans is present in the form of yeast in the human microbiome. The transition from yeast to the hyphal form is a transition into a pathogenic form $[22,23]$. The hyphal form is invasive, and in this form, the cells enter the host tissue by active penetration and induced endocytosis [24] (Figure 2). Induced endocytosis is mediated by hyphae invasion and depends on host activity, whereas active penetration depends on the fungal activity [25]. Several signaling pathways are involved in hyphal formation. The most important is cAMP-dependent protein kinase A (cyclic adenosine monophosphate PKA) [3,26].

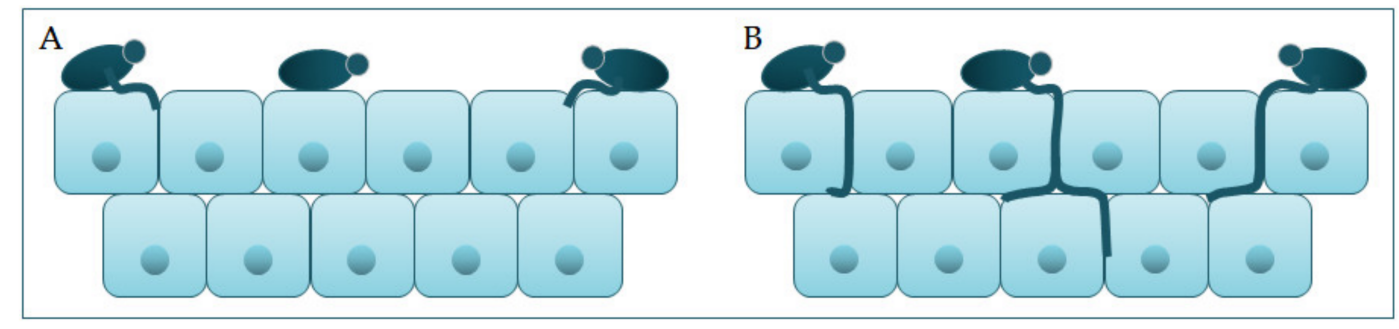

Figure 2. Schematic presentation of (A) adherence and colonization, and (B) penetration and invasion of C. albicans.

It has been shown that a hypha-specific toxin, candidalysin, is crucial for the occurrence of candidiasis $[19,27]$. Candidalysin is a cytolytic 31 -amino acid $\alpha$-helical amphipathic peptide $[19,28]$. It is produced by the C. albicans hyphae, and it is crucial in damaging the host cells. It is thought that it contributes to establishing a systemic infection and mortality [29]. Candidalysin is capable of directly damaging the epithelial membrane, by intercalation, permeabilization, and creating pores, causing the cytoplasmic contents to weaken $[29,30]$.

Factors that contribute to the pathogenic potential of Candida albicans are the expression of proteins important for adhesion and invasion. The process of adhesion is affected by various factors, such as the types of protein in the cell wall, and the physical and chemical properties of the cell surface. Adhesins of $C$. albicans recognize ligands such as proteins, fibrinogens, and fibronectins and bind to them [17]. Since adhesins such as Als3 and Hwp1 are mainly expressed during hyphae creation, they play an important role in the adhesion of C. albicans to the host cells [17].

Formation of biofilm is a property of C. albicans pathogenesis. Most infections caused by C. albicans are related to the creation of a biofilm on the surface of the host or on abiotic surfaces (implants), which leads to high morbidity and mortality [23]. Because C. albicans can transition from yeast to hyphae morphologically, its biofilm is a complex structure of different morphological forms [31]. The biofilm develops through several consecutive phases [32]. In the first phase, the individual cells of Candida albicans adhere to the substrate, which forms the basal layer of the biofilm. After that comes the phase of cell proliferation and filamentation, in which the cells form elongated protrusions, which continue growing into filamentous hyphal forms. The production of hyphae is a sign of the initiation of the creation of the biofilm. In the maturation phase, the accumulation of an extracellular 
polysaccharide matrix follows. The final phase involves the dispersion of non-adherent cells, which results in the possibility of the inception of new biofilms (Figure 3) and the possibility of dissemination in the tissue [33,34].

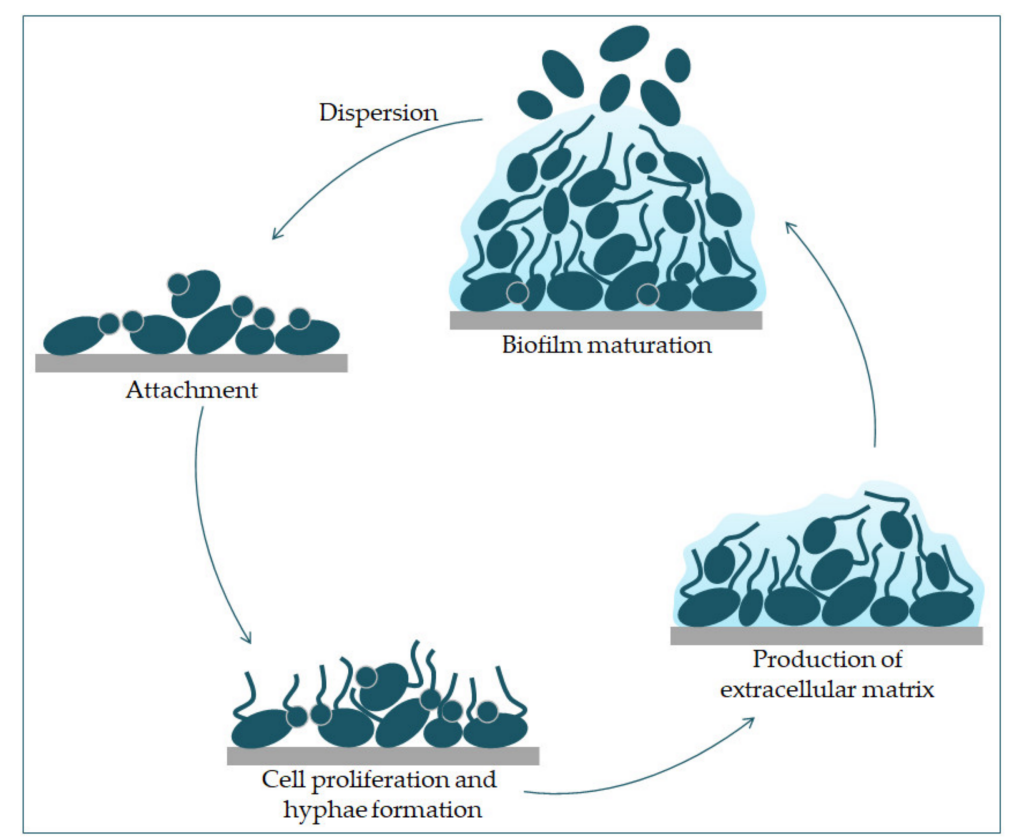

Figure 3. Phases of $C$. albicans biofilm formation. The formation starts with the attachment of yeast cells (green) to the surface (grey). In the early phase of the biofilm occurs the proliferation of C. albicans and hyphal cells' formation. The production of the extracellular matrix follows. The maturation phase includes the accumulation of an extracellular matrix. Finally, yeast cells disperse to a new site and form a new biofilm.

The extracellular polysaccharide matrix comprises extracellular polymers and extracellular DNA involved in maintaining the biofilm structure [35]. Additionally, extracellular DNA plays a vital role in binding the biofilm to the substrate [32]. An essential part of the extracellular matrix are $\beta$-1,3-glucans, which significantly contribute to the biofilm's resistance to antifungal drugs because they prevent contact with target cells [36]. C. albicans cells in biofilm release more $\beta$-1,3-glucans into the extracellular matrix than planktonic cells [37]. The biofilm channels facilitate cell supply with nutrients, air, and water, giving it new "multicellular" properties [32]. Intercellular communication, or quorum sensing, is an essential factor in forming biofilm and is based on microorganisms' behavior and the synthesis of signal molecules [38]. "Autoinducers" are signal molecules that regulate the population density by a signal mechanism. The binding of signal molecules to receptors suppresses target genes when a specific biofilm density is reached at a critical autoinducers concentration. This modulation of the quorum sensing process maintains the biofilm fungal colony's optimal size and encodes virulent phenotypes [32]. The transcription network that regulates biofilm formation consists of six major transcription regulators (Efg1, Tec1, Bcr1, Ndt80, Rob1, and Brg1) that regulate the expression of 1000 genes [39,40]. Bcr1 transcription factor (Biofilm and Cell wall Regulator 1), whose main target is Hwp1 (Hyphal Wall Protein), is necessary to form biofilm on mucosal surfaces [41]. The Hwp1 protein binds to transglutaminases on host cells in biofilms on mucosal surfaces. While on abiotic surfaces, it is expressed as an independent enzyme of the host and has an adhesion function [42]. Several different gene products control biofilm development on abiotic surfaces transcription factors (Efg1, Bcr1, Tye7), cell wall proteins (Hwp1, Als3), protein kinases (Ire1, Cbk1) [43]. The two essential regulators of biofilm on abiotic surfaces are Efg1 and Bcr1. These transcription factors are needed for the expression of different genes for cell adhesion and filamentation in biofilms on abiotic surfaces. Additionally, the adhesin 
Als3 which is the target of Bcr1 plays a crucial role in the formation of biofilm on the abiotic surface [43]. During the formation of a biofilm, besides the change in expression of genes directly involved in its formation, the expression of genes indirectly related to different characteristics of the biofilm also changes [44]. The expression of genes involved in the metabolism of sulfur-containing amino acids is increased, which is characteristic of cells in the biofilm's deeper layers. This metabolism allows cells to survive starvation and oxidative stress because sulfur amino acids are involved in the synthesis of antioxidants. The biofilm cells form a hypoxic environment and increase the expression of genes involved in glycolysis, fatty acid metabolism, and ergosterol synthesis [45].

Thigmotropism of the hyphae of C. albicans is regulated by the extracellular intake of calcium through calcium channels. It is an important mechanism in the enhancement of the virulence of Candida spp. Thigmotropism aids in creating a biofilm on abiotic surfaces and the spread in the host tissue [16].

Among virulence factors of $C$. albicans is phenotype transition between white and opaque cells. Phenotype diversity provides a quick response to changes in the environment. It is extremely important for the life of many microbe species. In Candida albicans cells, switching between two phenotype states, white and opaque, leads to differences in filamentous growth and interactions with immunological cells in vitro [46]. Morphological changes and phenotypic switches are stabilized transcriptionally and are stable for many generations [47].

Secretion of hydrolytic enzymes are present in Candida albicans. Hydrolytic enzymes facilitate the commensal and pathogenic characteristics such as attachment to host tissue and causing the host cell membrane's rupture. Because of these enzymes, invasion into the surfaces of mucous membrane and blood vessels is possible, and they also participate in avoiding the host's immune response. The three main enzymes produced by $C$. albicans are SAP (secreted aspartyl protease), phospholipase, and hemolysin [48].

\section{Clinical Manifestations of Candidiasis}

Candida albicans is part of the normal microbiota in about 50\% of individuals [49]. Candida sp. infections have various clinical manifestations, from superficial mucocutaneous disorders to an invasive infection affecting multiple organs [50]. We present here the clinical manifestations of C. albicans in the oral cavity, intestinal mucosa, skin, as well as in invasive infections.

\subsection{Candida albicans in the Oral Cavity}

Candidosis or candidiasis is the most common fungal infection in the oral cavity and is caused by Candida species. It was previously thought that $35 \%-80 \%$ of the population are carriers of oral Candida. Recent research using molecular detection methods suggests that Candida spp. are found in all humans as part of the normal oral flora [51,52]. The most common species in infected and healthy mouths is Candida albicans, and it is estimated to be found in over $80 \%$ of oral fungal isolates. Other types of Candida, the so-called non-albicans Candida species present in the mouth are C. glabrata, C. dubliniensis, C. parapsilosis, C. krusei, and C. tropicalis [51,53-55].

Various systemic, local, hereditary, and environmental factors lead to disturbances in oral homeostasis. Consequently, the transition of the normal flora to the pathogen and an opportunistic infection occurs. The changes lead either to excessive Candida growth or to a change in the expression of its virulence factors [51,56]. The most common local predisposing factors for candidosis are poor oral hygiene, wearing mobile prosthetic replacements, orthodontic appliances, and obturators, dry mouth (xerostomia), smoking, and steroid inhalers use, a diet rich in carbohydrates, and diseases of the oral mucosa. The systemic predisposing factors described are age (risk groups are the elderly and newborns), pregnancy, antibiotic therapy, systemic corticosteroid therapy, diseases such as tumors and their therapy, diseases of the digestive system, nutritional deficiencies (iron, folic acid, and vitamin deficiency), endocrinopathy (diabetes, hypothyroidism, hypoparathyroidism, 
etc.), autoimmune diseases (Sjögren syndrome, etc.), HIV, and primary immunodeficiencies [57-59].

In HIV infection/AIDS, candidosis is an early sign of immunodeficiency and can indicate the immune status and disease progression in such patients $[59,60]$.

Oral candidosis has a wide range of clinical manifestations. Therefore, there is a division into primary candidosis when the infection affects only the oral cavity and perioral area and secondary candidosis when the infection occurs as part of systemic disease. The mucosa is already altered and suitable for infection and lesions associated with Candida spp. fungi. According to its clinical features, which include color change, candidosis is often divided into white and red [57,61]. The primary form includes four different conditions: pseudomembranous candidosis, acute erythematous candidosis, chronic erythematous candidosis, and chronic hyperplastic or nodular candidosis [51].

Pseudomembranous candidosis is the most common form and is characterized by white patches or plaques on the oral mucosa that can be easily detached by gentle scraping, because only the upper layer of the mucosal epithelium is infected. The possibility of removal is an accepted differential diagnostic feature that distinguishes this form of candidosis from other white accumulations in the mouth. It typically occurs in neonates (who are likely to become infected through the birth canal), anemic, and immunodeficient individuals (HIV, diabetes, malignancy), patients on topical steroid therapy, and those with xerostomia. Lesions may be localized and generalized, most commonly affecting the tongue, buccal mucosa, soft and hard palate. It is often accompanied by taste disturbances and a bad taste in the mouth $[51,57,61,62]$.

Acute erythematous or atrophic candidosis occurs as a side-effect of systemic therapy with broad-spectrum antibiotics and immunosuppressants and corticosteroids, consequently altering the oral cavity's flora. It is clinically manifested as a painful red lesion on the dorsum of the tongue, and depapilation of the tongue is often present, with symptoms of burning and taste changes $[51,57,61]$.

Chronic erythematous or atrophic candidosis is also known as denture stomatitis or prosthetic palatitis. It is typical for patients who wear mobile acrylic prosthetic replacements and is most commonly found on the palate in people with total dentures. The onset of the disease is facilitated by poor oral hygiene and inadequate hygiene of the dentures. Lesions on the mucosa are red and limited to areas covered by the prosthetic replacement, sometimes accompanied by a burning sensation, but often are asymptomatic and detected only by dental examination $[51,57,61,63,64]$.

Chronic hyperplastic candidosis is also called Candida leukoplakia. Unlike the pseudomembranous form, these white deposits cannot be removed by light scraping. It is characterized by deep infiltration of the oral cavity tissue by the hyphae of the fungus. Most commonly, it is found on the lateral parts of the tongue and buccal mucosa. Clusters may be homogeneous or heterogeneous. Heterogeneous lesions are precancerous conditions because they are a predisposing factor for malignant transformation [51,61].

Among the secondary and other forms of Candida-related diseases, it is important to mention angular cheilitis, median rhomboid glossitis, and chronic mucocutaneous candidiasis [51,61].

Angular cheilitis is a disease of multiple etiologies that most often includes anatomical predisposition, xerostomia, immunosuppression, stomatitis caused by prosthetic replacements, and may or may not be associated with existing candidiasis in the mouth. It is an inflammatory condition of one, or more often, both corners of the lips and is clinically manifested by redness, erosions, and crusts that are sometimes covered with white plaque [61,63].

Median rhomboid glossitis is a condition of unknown etiology, often associated with secondary Candida infection. The change is located in the middle of the tongue, clinically manifested as a nodular or smooth lesion, and it is asymptomatic [51].

Chronic mucocutaneous candidiasis (CMC) is a heterogeneous group of conditions that reflect the inability to fight off candidial infections. It presents as recurrent, progressive 
candidiasis of the skin, nails, and mucosae [65]. The oral cavity changes initially resemble pseudomembranous candidosis, while later, they change into a hyperplastic form. It most commonly occurs in childhood and is associated with numerous immune disorders [66]. Defense against $C$. albicans is achieved by both the innate and adaptive host immune systems $[67,68]$. Research studies, especially CMC patients, have the elucidated mechanisms by which the primary innate and adoptive immune response develops during C. albicans infection. It has also been found that susceptibility factors differ significantly between gastrointestinal/vulvovaginal candidiasis and CMC infections. The former are much more dependent on micro-environmental factors, such as local nutrients, $\mathrm{pH}$, bile acids, and local commensal flora. At the same time, genomic sequencing of CMC patients revealed type 3 immunity defects, more specifically in Interleukine-17 (IL-17) pathways [69-71]. It was discovered that $\mathrm{T}$ helper (Th17) cells have a critical role in immune defense against Candida, but also a considerable role against other microbes [72,73]. Up to $80 \%$ of patients with childhood-onset CMC develop recurrent or severe infections with organisms other than Candida, including cutaneous dermatophyte infections and occasional bacterial septicemia $[65,74]$.

In addition to the mucosa, Candida spp. are present on all tooth surfaces-enamel, dentin, and cementum. C. albicans grows in enamel cracks and grooves and can penetrate through open dentin tubules $[75,76]$. Several Candida spp. have been isolated from dentin and root caries in children and adults, with a prevalence of $66 \%-97 \%$ in children and $31 \%-56 \%$ in adults $[76,77]$. Streptococcus mutans strains are considered to be the bacteria with the highest cariogenic potential, and in combination with Candida, this potential is increased. Bacterial and fungal cells are able to produce glucan, which, as an extracellular polysaccharide, helps create a cariogenic biofilm $[76,78]$. The presence of Candida spp. thus stimulates the growth of $S$. mutans and the volume of the biofilm $[79,80]$. There is evidence of interaction between $C$. albicans and Porphyromonas gingivalis, a bacterium considered the most important in developing periodontitis [81,82]. In a biofilm model, it has been shown that, in the presence of oxygen, $C$. albicans creates a protective environment for P. gingivalis $[81,83]$. To conclude, Candida plays a significant role in oral infections.

Treatment of mild to moderate oral infections caused by C. albicans usually consists of antifungal drugs applied topically to the inside of the oral cavity for 7 to 14 days. These are the antifungal drugs clotrimazole, miconazole, or nystatin. For severe infections, the antifungal drug fluconazole, taken orally or intravenously, is most commonly used [84].

\subsection{Candida albicans in Gastroenterology}

The gastrointestinal flora is unique in each individual and mostly constant in healthy people. There are differences in its composition along the digestive tract, and it varies from person to person depending on dietary or hygienic habits and age [4,85-87]. It is thought that humans are carriers of $C$. albicans by nature, and the gastrointestinal tract is one of the main stocks in the body. This species is the most common opportunistic pathogen among fungi and can cause diseases ranging from superficial to invasive and life-threatening infections [88]. The entry of C. albicans into the bloodstream and the development of disseminated candidiasis mostly occur after an invasive infection of the gastrointestinal system $[4,89,90]$. The main risk factors that promote the transition of $C$. albicans from a commensal or symbiotic to a pathogenic organism are dysbiosis of the residential microbiota, immune dysfunction, and damage to the muco-intestinal barrier [91].

At least one of four events is necessary for disseminated candidosis: direct invasion of epithelial cells (ECs) into blood capillaries and vessels, indirect translocation of C. albicans cells phagocytosed by host immune cells, direct damage of mucosal barriers, and spread from fungal biofilms [49,91].

The most common type of infectious esophagitis caused by fungi is esophageal candidosis caused by C. albicans [92,93]. The risk of infection exists in immunosuppressed persons (HIV / AIDS-esophagitis caused by C. albicans is an AIDS-defining disease, hematological malignancies, transplant patients), and in patients with comorbidities such as 
diabetes, alcohol consumption and smoking, antibiotic therapy, glucocorticoids, chemotherapy, radiotherapy, upper esophageal damage, and old age [92-96]. The clinical disease may be asymptomatic but is most commonly manifested by acute odynophagia, dysphagia, and pain behind the sternum [94,97]. Endoscopes show plaques of white to light yellow color on the mucosa, which cannot be washed off, and after their removal, the mucosa is red and ulcerative $[93,94]$. Esophageal candidosis, unlike oropharyngeal, should always be treated with systemic rather than topical antifungals. Three groups of drugs can be used in therapy: nystatin, amphotericin B, and azole antifungals (most commonly fluconazole), where the choice depends on the degree of immunosuppression [93,98]. Esophagitis caused by C. albicans is most often superficial, but complications and invasion with hematogenous dissemination (fungemia) are also possible and can subsequently lead to infection of other organs [93].

Fungal diseases of the gastroduodenum are less commonly reported. Mostly they occur as a secondary infection of individuals with tumors in this area, and they infiltrate benign or malignant ulcers that have a reduced ability to heal. Endoscopically, this looks like a white or grayish deposit that separates easily from the mucosa and is located at the base of the ulcer. The ulcer mostly heals with antiulcer therapy [99].

Possible intestinal infection may be superficial when the invasion is limited to the mucosa and submucosa, but can also be deep, where penetration is unlimited, and tissue destruction and perforation of the intestinal wall or spread to distant places occurs. Fungal infections are most commonly associated with inflammatory bowel disease (IBD). Predisposing factors are mucosal damage, mostly caused by surgery and chemotherapy, and impaired neutrophil function due to tumor therapy or long-term glucocorticoid use. When administering TNF $\alpha, C$. albicans should be suspected if infections are detected early during IBD treatment [100].

The interaction of C. albicans as a pathogen with the intestinal mucosa occurs in the form of adhesion, invasion, damage, and apoptosis. The main role in infection, and consequently pathogenicity, is played by substances secreted by the fungal hyphae $[89,91,101]$.

Increased colonization and infection increase the secretion of antimicrobial peptides (AMPs) by host cells, but $C$. albicans has developed mechanisms to avoid their activity as the first step in adherence to intestinal epithelial cells (IEC). In addition to defending against AMPs, C. albicans must break down the mucus's protective layer to reach the epithelial cell layer. After adhering to the mucins, it secretes mucinolytic enzymes. After the first contact with the IEC, most fungal cells convert to the hyphal form and express genes that promote adhesion by releasing adhesins and hyphal invasions. The release of surface molecules, i.e., adhesins, is crucial in the process of adhesion to the host tissue. It can also adhere to enterocytes via polysaccharide molecules on the cell wall surface [4,102-104].

Invasion by C. albicans takes place through two mechanisms, namely endocytosis and active penetration. Endocytosis is a host-driven process that does not require sustainable hyphae and occurs in the first four hours of interaction. Active penetration into the IEC is a procedure that requires sustainable forms of the fungus but does not require host activity and depends on the type of epithelial cells. It is thought that penetration takes place by the combination of mechanical pressure created by progressive elongation of the hyphae and lytic activity. This procedure allows C. albicans entry into enterocytes while the intercellular junctions remain intact. Unlike oral cells, fungi need specific genes to invade enterocytes [4,91].

Invasion of $C$. albicans fungi contributes to IEC damage and cell death. It is assumed that necrotic cell death is the main mechanism of damage observed during translocation of C. albicans through enterocytes. After the hyphae form, a cytolytic toxin called candidalysin is secreted, which is responsible for damaging host cells. It is the first peptide toxin identified in human fungal pathogens [4].

Antifungal therapy should be utilized in patients with intra-abdominal infections and risk factors for candidiasis, such as recent abdominal surgery, necrotizing pancreatitis, or anastomotic leakage. Additionally, infection source control should be included. The choice 
of antifungal therapy is similar to that for the treatment of candidaemia. An echinocandin is recommended as the initial therapy, while fluconazole is an alternative therapy. Azoles are used if the infection is not caused by Candida species resistant to them [105].

\subsection{Candida albicans in Dermatovenerology}

Candida spp. infections are one of the most common fungal infections in dermatology.

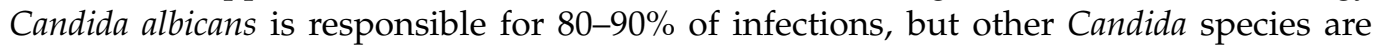
frequently seen as causative pathogens [74]. Candida infections are considered opportunistic in the majority of cases because Candida albicans is a normally commensal fungus. However, when host-immunity is impaired for various possible reasons, a pathogenic infection may occur [67]. Overall, a balance between the host defense system and the virulence factors of Candida albicans is the key to the commensal relationship. Candida albicans usually causes superficial skin infections, while "deep" mycoses, with the dermis and subcutis' involvement due to Candida, are rare. However, in severely immunocompromised patients, an invasive fungal infection may occur, resulting in deep penetration and systemic candidiasis, often with a fatal outcome.

Mucocutaneous candidiasis has a wide spectrum of clinical presentations. They depend on the affected body site, the patient's age group, and various predisposing factors. The unifying clinically relevant features of candidiasis are erythema, erosions, and easily removed cheesy white plaques. While white plaques are more often seen on mucosa than on skin, erythema and erosions are widely unspecific presentations. Therefore, taking a good anamnesis with special attention to the patient's potential predisposing factors is crucial for a dermatologist to establish a clinical suspicion of candidiasis. When typical body regions are affected, this is also a clue for a successful diagnosis.

The most common sites of involvement are intertriginous zones, e.g., submammary, inguinal folds, intergluteal creases, and pannus folds in overweight patients. Candida infections are present with sharply marked erythematous, sometimes erosive patches with light scaling of the surface, and satellite papules and pustules on the periphery [106]. These pustules are generally sterile and are called spongiform pustules due to the collections of neutrophils within the epidermis [74].

Candida also can cause chronic and acute paronychia and onychomycosis. Paronychia is inflammation of the skin around a nail (periungual area), also called whitlow, and is usually due to bacterial infection with Staphylococcus aureus and Pseudomonas spp. Onychomycosis is a fungal nail infection, and when caused by Candida, it is usually secondary to chronic paronychia [107].

Erosio interdigitalis blastomycetica (EIB) is another common Candida infection of the web space between the third and fourth fingers, usually in patients whose hands are frequently in water. It is assumed that this space is at least mobile, so the retention of water, sweat, and other potential irritative agents, such as soap, is most likely creating a perfect base for Candida infection. Typically, there is a central erosion surrounded by a rim of white macerated skin [108].

In rare cases, Candida albicans may cause folliculitis, usually of the beard area in an adult man with severe immunosuppression. In such cases, it can involve deep layers of skin with a clinical finding of deeper nodules around the hairs and pustules.

The genital area in men and women is a frequent site of Candida infection. Approximately 15-30\% of asymptomatic women are vaginal carriers of Candida spp.; during pregnancy, this rises to $40 \%$ [109]. It is assumed that almost every woman has at least one incident of vulvovaginal candidiasis in her lifetime. In men, balanitis and balanoposthitis are seen. In both sexes, the involvement of the perianal area is also possible. Even without clinical findings on the skin, localized pruritus of the genital and perianal area alone can be a sign of candidiasis [110].

Another presentation of Candida infection is diaper dermatitis. Diaper dermatitis is inflammation of the skin under the diaper, commonly seen in infants but also in incontinent adults. It is often a form of irritant contact dermatitis, but many cases are complicated with 
Candida superinfection. Diaper dermatitis is the cumulative result of several factors that damage the normal skin barrier. At first, occlusion that leads to skin maceration and skin contact with urine was suggested as the main reasons, but today fecal bacteria and the alkaline $\mathrm{pH}$ of urine are considered to have a greater role [74].

The skin of the newborns differs from that of adults in several ways. The possibility of Candida to produce disseminated cutaneous infection and systemic infection is thus higher, especially in premature newborns [111]. Congenital candidiasis represents an intrauterine infection. Extensive areas of erythema, papules, and pustules can be seen, as well as diffuse "burn-like" erythema, with desquamation and erosions [112]. Neonatal candidiasis is acquired during delivery or postnatally and is more similar to the adult presentation, involving more typical sites such as the diaper and intertriginous areas [113].

Besides earlier mentioned CMC, hyperimmunoglobulin E syndrome (HIES) is another group of inherited disorders characterized, among other things, by recurrent cutaneous candidiasis, occurring in approximately $80 \%$ of HIES patients [114,115]. Mutations in the STAT3 (signal transducer and activator of transcription 3) encoding gene cause the classic form of HIES, so susceptibility to Candida infections reveals the important role of STAT3dependent cytokines (e.g., IL-23, IL-21, IL-6) in the differentiation of IL-17 producing T helper cells [116].

Besides hereditary defects in host immunity mechanisms, numerous external factors contribute to candidial infections. As mentioned earlier, they are commonly seen in patients with diabetes mellitus [117-119], immunosuppressed patients, such as HIV / AIDS patients, oncology patients receiving chemotherapy, and organ transplant patients $[117,120,121]$ taking broad-spectrum systemic antibiotics [122,123]. In modern medicine, especially with emerging novel therapies, the number of such patients is growing, so Candida infections are also increased [68]. For example, remarkable advances are taking place in the treatment of immune-mediated inflammatory diseases (IMID). One of the important specific therapeutic targets is cytokine IL-17 because it plays a critical role in the pathogenesis of various IMIDs, including psoriasis [124-126]. Dermatologists working with patients receiving these therapies should warn them about the increased risk of candidiasis. As mentioned before, IL-17 pathways play a critical role in the host defense against Candida, so blocking them will obviously result in greater susceptibility to infection [126,127].

The strategy for treating cutaneous candidiasis depends on the infection's location, its extensiveness, and the patient's immune status. Most usually respond to topical antifungal agents, but if the patient is immunocompromised, has extensive areas affected, or fails to respond to topical therapy, systemic treatment is needed [128]. Although many antifungal agents are available, not all of them are effective against Candida [105]. Limited effectiveness is not the only therapeutic challenge. Today, there is increasing pathogen resistance to antifungal agents, and Candida species are among them $[67,129]$. Generally, mucocutaneous candidiasis responds well to topical azoles (miconazole, clotrimazole, and econazole) $[74,105,130]$. Of the topical polyenes, nystatin is most commonly used, especially for oral and vulvovaginal candidiasis $[105,131]$. An antifungal agent that is more effective against Candida than the azoles, allylamines, or benzylamines is ciclopirox olamine. It is increasingly being used in dermatology practice [132,133]. If systemic treatment is necessary, fluconazole is generally the drug of choice [105]. However, recently azole-resistant strains have been detected [134]. Alternative choices are itraconazole or one of the second-generation triazoles available. If the patient is not responding to treatment with azoles, then amphotericin B therapy should be tried. Members of the echinocandin class of antifungal drugs (micafungin, anidulafungin, caspofungin acetate) also showed effectiveness in Candida infections [105,135]. Until recently, ketoconazole was also commonly used, but the EMA and FDA have withdrawn it due to potential hepatotoxicity, and today its use is restricted to only complicated, non-responsive fungal infections [136]. Its systemic use is limited in several countries, although it is still being used locally (as shampoo).

The most common side effect of topical antifungals is local skin irritation, but rarely true allergic contact dermatitis. Systemic antifungal drugs may cause severe cutaneous re- 
actions, including toxic epidermal necrolysis and Stevens-Johnson syndrome. Fluconazole can cause potential hepatic damage. The main mechanism of hepatotoxicity is drug-drug interactions caused by inhibition of cytochrome P450 enzymes, which play a major role in the metabolism of lipophilic drugs. All systemic antifungals should be used with caution in patients with renal or liver disease [137].

To conclude, it is worth mentioning traditional topical medications, used additionally in the treatment of cutaneous candidiasis: potassium permanganate $\left(\mathrm{KMnO}_{4}\right)$, gentian violet solution, Burow's solution (aluminum acetate) [74]. Additionally, in the search for novel antifungal preparations, the use of silver has reemerged [138]. Recently, the effect of silver nanoparticles (AgNPs) on various dermatophytes and yeasts, including Candida spp. was tested, and many studies showed that AgNPs have potential in the treatment of candidiasis $[139,140]$.

\subsection{Invasive Candida albicans Infections}

Invasive candidiasis refers to bloodstream infections caused by Candida spp. Most often occur after passing through the intestinal barrier. For example, after surgery, it could spread to the abdominal cavity, and enter the bloodstream and cause candidiasis [141]. C. albicans overgrowth can trigger an impairment of the immune response, leading to opportunistic infections in various organs, i.e., invasive candidiasis [142]. Therefore, the invasive disease is usually the result of increased or abnormal colonization, along with local or generalized lack of host defense [143]. Invasive candidiasis is not a single clinical entity but is a disorder with countless clinical manifestations that can potentially affect any organ [141] (Table 1). Invasive candidiasis is closely related to medical technology development and is widely recognized as a significant cause of morbidity and mortality in the health care environment [144]. At least 15 different Candida spp. can cause infections in humans. However, five pathogens cause the most invasive infections: Candida albicans, Candida glabrata, Candida tropicalis, Candida parapsilosis, and Candida krusei, but the most common pathogen in the clinical setting is C. albicans [141].

Table 1. Invasive candidiasis in various organs.

\begin{tabular}{|c|c|c|c|c|c|c|}
\hline Bone & Brain & Eye & Heart & Kidney & Liver and Spleen & Lung \\
\hline Osteomyelitis & Brain abscess & Choroiditis & Endocarditis & Candiduria & $\begin{array}{c}\text { Chronic } \\
\text { disseminated } \\
\text { candidiasis }\end{array}$ & Focal abscess \\
\hline \multirow[t]{3}{*}{ Spondylodiscitis } & $\begin{array}{l}\text { Meningo- } \\
\text { encephalitis }\end{array}$ & Retinitis & & Pyelonephritis & Focal abscess & \\
\hline & & Endophthalmitis & & Pyonephrosis & & \\
\hline & & & & Renal abscess & & \\
\hline
\end{tabular}

Invasive Candida infections are most often associated with candidemia (Candida species in the blood), primarily in immunosuppressed patients and those requiring intensive care. Immunosuppressed patients are at special risk for candidemia, including those with hematological malignancies (in patients who have just recovered from an episode of neutropenia), recipients of hematopoietic cell transplants or solid organ, and those given chemotherapeutic agents for a variety of different diseases. Other risk factors are associated with extensive gastrointestinal mucosal damage, broad-spectrum antibiotics, and central venous catheters. Candida albicans is the most typical cause of candidiasis, although many Candida species other than albicans have been isolated in recent years $[105,145]$. When C. albicans enters the bloodstream, it can cause infections of the bladder and kidneys, endophthalmitis, meningitis, osteoarticular infections, endocarditis, peritonitis and intra-abdominal infections, pneumonia, empyema, mediastinitis, and pericarditis.

Candiduria refers to the presence of Candida in the urine. Candiduria as a source of candidemia typically occurs in patients who have urinary tract abnormalities, most often 
urinary tract obstruction, and/or in those who have undergone a urinary tract procedure. It is common in hospitalized patients, although it is often challenging to distinguish colonization from a bladder infection. Renal transplantation was thought to be a risk factor for ascending infection and candidemia when candiduria was present. Studies show that more than $50 \%$ of hospitalized patients with candiduria have Candida albicans isolated [146,147].

C. albicans does not often cause clinically meaningful pneumonia in adults. Despite that, Candida albicans is often isolated from patients' respiratory tracts in intensive care units, intubated patients, or patients with a chronic tracheostomy. In most cases, this reflects colonization of the airways and not an infection [105]. Candida pneumonia has been noted in seriously immunocompromised patients with disseminated conditions, deficient birth weight newborns, and individuals with malignancies [148-150]. Since contamination issues confuse an antemortem diagnosis, a final diagnosis of invasive Candida pneumonia needs histological verification, which is typically achieved only at autopsy. A bronchoalveolar lavage is a diagnostic tool for verifying pneumonia and determining the causative pathogen [151].

Candida species infect bones and joints due to either hematogenous seeding or inoculation during trauma, intra-articular injection, a surgical procedure, or injection drug use. Osteoarticular infections often become symptomatic months or as long as a year after an episode of fungemia or a surgical procedure. The manifestations are generally more subtle than bacterial infections at the same sites. Both of these factors contribute to long delays in diagnosis, especially in patients with vertebral osteomyelitis. The major symptoms of Candida arthritis are pain and decreased range of motion, whereas local pain is the predominant symptom of Candida osteomyelitis. Only one Candida colony is considered pathogenic in a biopsy or aspirate culture of joint fluid or bone [152-154].

Candida infections of the central nervous system most typically affect the meninges (although they are all generally uncommon). This most often happens in premature infants. The infection may be secondary to hematogenous spread or direct inoculation. Predisposing factors include neurosurgery, newer antibiotics, and corticosteroids. Fever, meningismus, elevated cerebrospinal fluid pressure, and localizing neurological signs are often present. Candida albicans seems to be the most pathogenic Candida spp., leading to increased mortality rates in invasive infection when compared to other Candida species $[155,156]$.

Fungal endocarditis represents $1-6 \%$ of the total spectrum of endocarditis. Candida endocarditis is one of the most severe candidiasis manifestations and is the most common cause of fungal endocarditis [157]. Due to the rarity of candidal infective endocarditis, the prognosis, epidemiology, and optimal treatment of Candida infective endocarditis have been insufficiently described. Therapy procedures are obtained mainly from single-site case series and case reports. Candida endocarditis results from candidemia and is usually seen in patients with prosthetic heart valves, people who inject intravenous drugs, and in patients who have indwelling central venous catheters and prolonged fungemia [158].

Candida albicans (and other yeasts) can cause nosocomial infections, which involve the transmission by the hands of healthcare professionals or contaminated material (e.g., rinsing the central venous catheter with saline used for multiple patients) [141,159]. Critical challenges in treating candidaemia and invasive candidiasis include prevention, early detection, and rapid initiation of appropriate systemic antifungal therapy. The untimely initiation of treatment could result in poorer clinical outcomes [160,161]. The emergence of antifungal resistance is a new problem globally, which is an additional concern in treating infections caused by C. albicans and other Candida sp. [162-164]. Published data suggest that fluconazole antifungal prophylaxis reduces the incidence of invasive candidiasis among high-risk ICU patients [165]. However, it should be borne in mind that antifungal prophylaxis may favor resistance development [163]. Targeted antifungal prophylaxis is warranted in high-risk recipients of the liver, pancreas, small intestine, or hematopoietic stem cells [166]. The control of the infection source and early initiation of treatment with effective systemic antifungal therapy, usually before the diagnosis of invasive candidiasis is 
confirmed, is crucial for successfully treating invasive candidiasis [141,167]. Source control refers to removing the infection source, such as removing contaminated intravascular catheters, drainage of peritoneal fluid, pleural fluid, or abscesses [12,168]. To successfully treat the infection, it is sometimes necessary to remove infected prosthetic devices, such as a pacemaker, an artificial joint, or other prosthetic devices, if possible [169]. In addition to controlling the source of infection, early effective antifungal therapy is crucial in successfully treating patients with invasive candidiasis. The data indicate significantly higher mortality when antifungal therapy is delayed or inadequate or when rapid source control has not been achieved $[105,141,170]$.

Several published guidelines outline expert recommendations for treating invasive candidiasis, with detailed recommendations for specific clinical circumstances [105,171-173] (Table 2). The selection of an antifungal drug for initial treatment should be based on prior testing of an isolated strain of $C$. albicans for antifungal drugs, the patient's sensitivity to the antifungal agent, and the severity of the disease, relevant comorbidities, and brain involvement, heart valves, or internal organs $[174,175]$. Specific clinical units should also consider data on susceptibility to Candida spp. infections.

Table 2. The recommended treatments of invasive candidiasis.

\begin{tabular}{ccc}
\hline \multicolumn{3}{c}{ Candida albicans } \\
\hline Preferred Initial Therapy & Alternative Initial Therapy & Preferred Step-Down Therapy \\
\hline Echinocandin & Fluconazole & Fluconazole \\
\hline
\end{tabular}

\section{Conclusions}

It is extremely important to know the factors and mechanisms of the pathogenicity of $C$. albicans precisely because of their wide range, from dimorphism, biofilm formation, thigmotropism, expression of adhesion proteins, and secretion of extracellular hydrolytic enzymes. C. albicans is able to cause infections ranging from superficial to systemic and life-threatening.

In addition to knowing the virulence factors, knowledge of the essential predisposing factors for the development of candidiasis is also necessary, such as neutropenia, immunosuppression, diabetes, age, as well as factors related to patient care, long-term antimicrobial therapy, long-term hospitalization, catheter use, and surgery.

As knowledge of all these factors increases, the possibility of prevention increases, as we work to prevent the occurrence of infections caused by C. albicans, and opportunities are created to develop new diagnostic and therapeutic possibilities.

Author Contributions: Writing the manuscript: J.T., M.J., T.M., E.P., S.B., and I.K.; updating the text: J.T. and I.Š.; literature searches: J.T., M.J., T.M., E.P., S.B., I.K., and I.Š.; figure drawings: I.Š.; critical reviewing of the manuscript: I.Š.; organization and editing of the manuscript: I.Š. All authors have read and agreed to the published version of the manuscript.

Funding: This research received no external funding.

Institutional Review Board Statement: Not applicable.

Informed Consent Statement: Not applicable.

Conflicts of Interest: The authors declare no conflict of interest. The funders had no role in the design of the study; in the collection, analyses, or interpretation of data; in the writing of the manuscript, or in the decision to publish the results.

\section{References}

1. Mukaremera, L.; Lee, K.K.; Mora-Montes, H.M.; Gow, N.A.R. Candida albicans yeast, pseudohyphal, and hyphal morphogenesis differentially affects immune recognition. Front. Immunol. 2017, 8, 1. [CrossRef] [PubMed]

2. Morad, H.O.J.; Wild, A.-M.; Wiehr, S.; Davies, G.; Maurer, A.; Pichler, B.J.; Thornton, C.R. Pre-clinical Imaging of Invasive Candidiasis Using ImmunoPET/MR. Front. Microbiol. 2018, 9, 1996. [CrossRef] [PubMed] 
3. Chen, H.; Zhou, X.; Ren, B.; Cheng, L. The regulation of hyphae growth in Candida albicans. Virulence 2020, 11, 337-348. [CrossRef] [PubMed]

4. $\quad$ Basmaciyan, L.; Bon, F.; Paradis, T.; Lapaquette, P.; Dalle, F. Candida Albicans Interactions with The Host: Crossing The Intestinal Epithelial Barrier. Tissue Barriers 2019, 7, 1612661. [CrossRef]

5. Walker, G.M.; White, N.A. Introduction to Fungal Physiology. In Fungi: Biology and Applications; Kavanagh, K., Ed.; WileyBlackwell: Chichester, UK, 2017; p. 4. ISBN 978-1-119-37432-9.

6. Molero, G.; Díez-Orejas, R.; Navarro-García, F.; Monteoliva, L.; Pla, J.; Gil, C.; Sánchez-Pérez, M.; Nombela, C. Candida albicans: Genetics, dimorphism and pathogenicity. Int. Microbiol. 1998, 1, 95-106.

7. Kornitzer, D. Regulation of candida albicans hyphal morphogenesis by endogenous signals. J. Fungi 2019, 5. [CrossRef]

8. Basso, V.; d'Enfert, C.; Znaidi, S.; Bachellier-Bassi, S. From genes to networks: The regulatory circuitry controlling candida albicans morphogenesis. In Fungal Physiology and Immunopathogenesis: Current Topics in Microbiology and Immunology; Rodrigues, M., Ed.; Springer: Berlin/Heidelberg, Germany, 2019; Volume 422, pp. 61-99.

9. Garcia-Rubio, R.; de Oliveira, H.C.; Rivera, J.; Trevijano-Contador, N. The Fungal Cell Wall: Candida, Cryptococcus, and Aspergillus Species. Front. Microbiol. 2020, 10, 2993. [CrossRef]

10. Höfs, S.; Mogavero, S.; Hube, B. Interaction of Candida albicans with host cells: Virulence factors, host defense, escape strategies, and the microbiota. J. Microbiol. 2016, 54, 149-169. [CrossRef]

11. Reyna-Beltrán, E.; Isaac Bazán Méndez, C.; Iranzo, M.; Mormeneo, S.; Pedro Luna-Arias, J. The Cell Wall of Candida albicans: A Proteomics View. In Candida Albicans; Sandai, D., Ed.; IntechOpen: London, UK, 2019.

12. Ciurea, C.N.; Kosovski, I.-B.; Mare, A.D.; Toma, F.; Pintea-Simon, I.A.; Man, A. Candida and Candidiasis-Opportunism Versus Pathogenicity: A Review of the Virulence Traits. Microorganisms 2020, 8, 857. [CrossRef]

13. Hall, R.A. Dressed to impress: Impact of environmental adaptation on the Candida albicans cell wall. Mol. Microbiol. 2015, 97, 7-17. [CrossRef]

14. Jordá, T.; Puig, S. Regulation of Ergosterol Biosynthesis in Saccharomyces cerevisiae. Genes 2020, 11, 795. [CrossRef] [PubMed]

15. Cho, I.; Jackson, M.R.; Swift, J. Roles of Cross-Membrane Transport and Signaling in the Maintenance of Cellular Homeostasis. Cell. Mol. Bioeng. 2016, 9, 234-246. [CrossRef] [PubMed]

16. Viana, R.; Dias, O.; Lagoa, D.; Galocha, M.; Rocha, I.; Teixeira, M.C. Genome-Scale Metabolic Model of the Human Pathogen Candida albicans: A Promising Platform for Drug Target Prediction. J. Fungi 2020, 6, 171. [CrossRef] [PubMed]

17. Deorukhkar, S.C. Virulence Traits Contributing to Pathogenicity of Candida Species. J. Microbiol. Exp. 2017, 5. [CrossRef]

18. Noble, S.M.; Gianetti, B.A.; Witchley, J.N. Candida albicans cell-type switching and functional plasticity in the mammalian host. Nat. Rev. Microbiol. 2017, 15, 96-108. [CrossRef]

19. Hanaoka, M.; Domae, E. IL-1 $\alpha$ released from oral epithelial cells upon candidalysin exposure initiates an early innate epithelial response. Int. Immunol. 2020. [CrossRef]

20. Gale, C.; Gerami-Nejad, M.; McClellan, M.; Vandoninck, S.; Longtine, M.S.; Berman, J. Candida albicans Int1p Interacts with the Septin Ring in Yeast and Hyphal Cells. Mol. Biol. Cell 2001, 12, 3538-3549. [CrossRef]

21. Sudbery, P.E. Growth of Candida albicans hyphae. Nat. Rev. Microbiol. 2011, 9, 737-748. [CrossRef]

22. Mayer, F.L.; Wilson, D.; Hube, B. Candida albicans pathogenicity mechanisms. Virulence 2013, 4, 119-128. [CrossRef]

23. Tsui, C.; Kong, E.F.; Jabra-Rizk, M.A. Pathogenesis of Candida albicans biofilm. Pathog. Dis. 2016, 74, ftw018. [CrossRef]

24. Maza, P.K.; Bonfim-Melo, A.; Padovan, A.C.B.; Mortara, R.A.; Orikaza, C.M.; Ramos, L.M.D.; Moura, T.R.; Soriani, F.M.; Almeida, R.S.; Suzuki, E.; et al. Candida albicans: The ability to invade epithelial cells and survive under oxidative stress is unlinked to hyphal length. Front. Microbiol. 2017, 8. [CrossRef] [PubMed]

25. Galocha, M.; Pais, P.; Cavalheiro, M.; Pereira, D.; Viana, R.; Teixeira, M.C. Divergent approaches to virulence in C. Albicans and C. Glabrata: Two sides of the same coin. Int. J. Mol. Sci. 2019, 20, 2345. [CrossRef] [PubMed]

26. Lin, C.J.; Chen, Y.L. Conserved and divergent functions of the CAMP/PKA signaling pathway in candida albicans and candida tropicalis. J. Fungi 2018, 4, 68. [CrossRef] [PubMed]

27. Moyes, D.L.; Wilson, D.; Richardson, J.P.; Mogavero, S.; Tang, S.X.; Wernecke, J.; Höfs, S.; Gratacap, R.L.; Robbins, J.; Runglall, M.; et al. Candidalysin is a fungal peptide toxin critical for mucosal infection. Nature 2016, 532, 64-68. [CrossRef] [PubMed]

28. Naglik, J.R.; Gaffen, S.L.; Hube, B. Candidalysin: Discovery and function in Candida albicans infections. Curr. Opin. Microbiol. 2019, 52, 100-109. [CrossRef]

29. Kasper, L.; König, A.; Koenig, P.A.; Gresnigt, M.S.; Westman, J.; Drummond, R.A.; Lionakis, M.S.; Groß, O.; Ruland, J.; Naglik, J.R.; et al. The fungal peptide toxin Candidalysin activates the NLRP3 inflammasome and causes cytolysis in mononuclear phagocytes. Nat. Commun. 2018, 9, 1-20. [CrossRef]

30. König, A.; Hube, B.; Kasper, L. The Dual Function of the Fungal Toxin Candidalysin during Candida albicans-Macrophage Interaction and Virulence. Toxins 2020, 12, 469. [CrossRef]

31. Priya, A.; Pandian, S.K. Piperine Impedes Biofilm Formation and Hyphal Morphogenesis of Candida albicans. Front. Microbiol. 2020, 11. [CrossRef]

32. Talapko, J.; Škrlec, I. The Principles, Mechanisms, and Benefits of Unconventional Agents in the Treatment of Biofilm Infection. Pharmaceuticals 2020, 13, 299. [CrossRef]

33. McCall, A.D.; Pathirana, R.U.; Prabhakar, A.; Cullen, P.J.; Edgerton, M. Candida albicans biofilm development is governed by cooperative attachment and adhesion maintenance proteins. NPJ Biofilms Microbiomes 2019, 5, 1-12. [CrossRef] 
34. Cavalheiro, M.; Teixeira, M.C. Candida Biofilms: Threats, challenges, and promising strategies. Front. Med. 2018, 5, 28. [CrossRef] [PubMed]

35. Li, W.; Wang, J.J.; Qian, H.; Tan, L.; Zhang, Z.; Liu, H.; Pan, Y.; Zhao, Y. Insights into the Role of Extracellular DNA and Extracellular Proteins in Biofilm Formation of Vibrio parahaemolyticus. Front. Microbiol. 2020, 11. [CrossRef] [PubMed]

36. Karygianni, L.; Ren, Z.; Koo, H.; Thurnheer, T. Biofilm Matrixome: Extracellular Components in Structured Microbial Communities. Trends Microbiol. 2020, 28, 668-681. [CrossRef] [PubMed]

37. Nett, J.E.; Andes, D.R. Contributions of the biofilm matrix to candida pathogenesis. J. Fungi 2020, 6, 21. [CrossRef]

38. Paluch, E.; Rewak-Soroczyńska, J.; Jędrusik, I.; Mazurkiewicz, E.; Jermakow, K. Prevention of biofilm formation by quorum quenching. Appl. Microbiol. Biotechnol. 2020, 104, 1871-1881. [CrossRef]

39. Perry, A.M.; Hernday, A.D.; Nobile, C.J. Unraveling How Candida albicans Forms Sexual Biofilms. J. Fungi 2020, 6, 14. [CrossRef]

40. Glazier, V.E.; Murante, T.; Murante, D.; Koselny, K.; Liu, Y.; Kim, D.; Koo, H.; Krysan, D.J. Genetic analysis of the Candida albicans biofilm transcription factor network using simple and complex haploinsufficiency. PLoS Genet. 2017, 13, e1006948. [CrossRef]

41. Rodríguez-Cerdeira, C.; Martínez-Herrera, E.; Carnero-Gregorio, M.; López-Barcenas, A.; Fabbrocini, G.; Fida, M.; El-Samahy, M.; González-Cespón, J.L. Pathogenesis and Clinical Relevance of Candida Biofilms in Vulvovaginal Candidiasis. Front. Microbiol. 2020, 11, 2884. [CrossRef]

42. Bartnicka, D.; Karkowska-Kuleta, J.; Zawrotniak, M.; Satała, D.; Michalik, K.; Zielinska, G.; Bochenska, O.; Kozik, A.; Ciaston, I.; Koziel, J.; et al. Adhesive protein-mediated cross-talk between Candida albicans and Porphyromonas gingivalis in dual species biofilm protects the anaerobic bacterium in unfavorable oxic environment. Sci. Rep. 2019, 9. [CrossRef]

43. Ganguly, S.; Mitchell, A.P. Mucosal biofilms of Candida albicans. Curr. Opin. Microbiol. 2011, 14, 380-385. [CrossRef]

44. Murillo, L.A.; Newport, G.; Lan, C.Y.; Habelitz, S.; Dungan, J.; Agabian, N.M. Genome-wide transcription profiling of the early phase of biofilm formation by Candida albicans. Eukaryot. Cell 2005, 4, 1562-1573. [CrossRef] [PubMed]

45. Bonhomme, J.; d'Enfert, C. Candida albicans biofilms: Building a heterogeneous, drug-tolerant environment. Curr. Opin. Microbiol. 2013, 16, 398-403. [CrossRef] [PubMed]

46. Mallick, E.M.; Bergeron, A.C.; Jones, S.K.; Newman, Z.R.; Brothers, K.M.; Creton, R.; Wheeler, R.T.; Bennett, R.J. Phenotypic Plasticity Regulates Candida albicans Interactions and Virulence in the Vertebrate Host. Front. Microbiol. 2016, 7, 780. [CrossRef] [PubMed]

47. Brimacombe, C.A.; Sierocinski, T.; Dahabieh, M.S. A white-to-opaque-like phenotypic switch in the yeast Torulaspora microellipsoides. Commun. Biol. 2020, 3, 1-11. [CrossRef] [PubMed]

48. Wibawa, T. The role of virulence factors in Candida albicans pathogenicity. J. Med. Sci. 2016, 48, 58-68. [CrossRef]

49. Nobile, C.J.; Johnson, A.D. Candida albicans Biofilms and Human Disease. Annu. Rev. Microbiol. 2015, 69, 71-92. [CrossRef]

50. Naglik, J.R.; Challacombe, S.J.; Hube, B. Candida albicans Secreted Aspartyl Proteinases in Virulence and Pathogenesis. Microbiol. Mol. Biol. Rev. 2003, 67, 400-428. [CrossRef]

51. Lewis, M.A.O.; Williams, D.W. Diagnosis and management of oral candidosis. Br. Dent. J. 2017, 223, 675-681. [CrossRef]

52. Peters, B.A.; Wu, J.; Hayes, R.B.; Ahn, J. The oral fungal mycobiome: Characteristics and relation to periodontitis in a pilot study. BMC Microbiol. 2017, 17, 157. [CrossRef]

53. Sav, H.; Altinbas, R.; Bestepe Dursun, Z. Fungal profile and antifungal susceptibility pattern in patients with oral candidiasis. Infez. Med. 2020, 28, 392-396.

54. Aslani, N.; Janbabaei, G.; Abastabar, M.; Meis, J.F.; Babaeian, M.; Khodavaisy, S.; Boekhout, T.; Badali, H. Identification of uncommon oral yeasts from cancer patients by MALDI-TOF mass spectrometry. BMC Infect. Dis. 2018, 18, 24. [CrossRef] [PubMed]

55. Rafiq, N.B. Candidiasis. StatPearls 2020, 1261-1267. [CrossRef]

56. Zdanavičienè, E.; Sakalauskienè, J.; Gleiznys, A.; Gleiznys, D.; Žilinskas, J. Host responses to Candida albicans. A review. Stomatologija 2017, 19, 109-123. [PubMed]

57. Baumgardner, D.J. Oral Fungal Microbiota: To Thrush and Beyond. J. Patient-Cent. Res. Rev. 2019, 6, 252-261. [CrossRef]

58. Serrano, J.; López-Pintor, R.M.; Ramírez, L.; Fernández-Castro, M.; Sanz, M.; Melchor, S.; Peiteado, D.; Hernández, G. Risk factors related to oral candidiasis in patients with primary Sjögren's syndrome. Med. Oral Patol. Oral Cir. Bucal 2020, 25, e700-e705. [CrossRef]

59. Suryana, K.; Suharsono, H.; Antara, I.G.P.J. Factors associated with oral candidiasis in people living with HIV/AIDS: A case control study. HIV/AIDS Res. Palliat. Care 2020, 12, 33-39. [CrossRef]

60. Du, X.; Xiong, H.; Yang, Y.; Yan, J.; Zhu, S.; Chen, F. Dynamic study of oral Candida infection and immune status in HIV infected patients during HAART. Arch. Oral Biol. 2020, 115, 104741. [CrossRef]

61. Hellstein, J.W.; Marek, C.L. Candidiasis: Red and White Manifestations in the Oral Cavity. Head Neck Pathol. 2019, 13, 25-32. [CrossRef]

62. Millsop, J.W.; Fazel, N. Oral candidiasis. Clin. Dermatol. 2016, 34, 487-494. [CrossRef]

63. O'Donnell, L.E.; Millhouse, E.; Sherry, L.; Kean, R.; Malcolm, J.; Nile, C.J.; Ramage, G. Polymicrobial Candida biofilms: Friends and foe in the oral cavity. FEMS Yeast Res. 2015, 15. [CrossRef]

64. Gad, M.M.; Fouda, S.M. Current perspectives and the future of candida albicans-associated denture stomatitis treatment. Dent. Med. Probl. 2020, 57, 95-102. [CrossRef]

65. Kirkpatrick, C.H.; Hill, H.R. Chronic mucocutaneous candidiasis. Pediatr. Infect. Dis. J. 2001, 20, 197-206. [CrossRef] [PubMed] 
66. Sanghvi, R.; Siddik, D.; Hullah, E.; Shah, T.; Carey, B. Chronic mucocutaneous candidiasis: A rare diagnosis in paediatric dentistry. Br. J. Oral Maxillofac. Surg. 2020, 58, 708-710. [CrossRef] [PubMed]

67. Qin, Y.; Zhang, L.; Xu, Z.; Zhang, J.; Jiang, Y.Y.; Cao, Y.; Yan, T. Innate immune cell response upon Candida albicans infection. Virulence 2016, 7, 512-526. [CrossRef] [PubMed]

68. Richardson, J.P.; Moyes, D.L. Adaptive immune responses to Candida albicans infection. Virulence 2015, 6, 327-337. [CrossRef] [PubMed]

69. Kumamoto, C.A. Inflammation and gastrointestinal Candida colonization. Curr. Opin. Microbiol. 2011, 14, 386-391. [CrossRef] [PubMed]

70. Cassone, A. Vulvovaginal Candida albicans infections: Pathogenesis, immunity and vaccine prospects. BJOG Int. J. Obstet. Gynaecol. 2015, 122, 785-794. [CrossRef] [PubMed]

71. Kashem, S.W.; Kaplan, D.H. Skin Immunity to Candida albicans. Trends Immunol. 2016, 37, 440-450. [CrossRef] [PubMed]

72. Ng, W.F.; Von Delwig, A.; Carmichael, A.J.; Arkwright, P.D.; Abinun, M.; Cant, A.J.; Jolles, S.; Lilic, D. Impaired TH17 responses in patients with chronic mucocutaneous candidiasis with and without autoimmune polyendocrinopathy-candidiasis- ectodermal dystrophy. J. Allergy Clin. Immunol. 2010, 126. [CrossRef]

73. Soltész, B.; Tóth, B.; Sarkadi, A.K.; Erdos, M.; Maródi, L. The evolving view of IL-17-mediated immunity in defense against mucocutaneous candidiasis in humans. Int. Rev. Immunol. 2015, 34, 348-363. [CrossRef]

74. Bolognia, J.; Schaffer, J.; Cerroni, L. Dermatology, 4th ed.; Elsevier: Amsterdam, The Netherlands, 2018; Volume 2, ISBN 978-07020-6275-9.

75. Chevalier, M.; Ranque, S.; Prêcheur, I. Oral fungal-bacterial biofilm models in vitro: A review. Med. Mycol. 2018, 56, 653-667. [CrossRef]

76. Salehi, B.; Kregiel, D.; Mahady, G.; Sharifi-Rad, J.; Martins, N.; Rodrigues, C.F. Management of Streptococcus mutans-Candida spp. Oral Biofilms' Infections: Paving the Way for Effective Clinical Interventions. J. Clin. Med. 2020, 9, 517. [CrossRef]

77. Pereira, D.F.A.; Seneviratne, C.J.; Koga-Ito, C.Y.; Samaranayake, L.P. Is the oral fungal pathogen Candida albicans a cariogen? Oral Dis. 2018, 24, 518-526. [CrossRef]

78. Yoo, H.J.; Jwa, S.K. Inhibitory effects of $\beta$-caryophyllene on Streptococcus mutans biofilm. Arch. Oral Biol. 2018, 88, 42-46. [CrossRef]

79. Sampaio, A.A.; Souza, S.E.; Ricomini-Filho, A.P.; Del Bel Cury, A.A.; Cavalcanti, Y.W.; Cury, J.A. Candida albicans Increases Dentine Demineralization Provoked by Streptococcus mutans Biofilm. Caries Res. 2019, 53, 322-331. [CrossRef]

80. Abrantes, P.M.D.S.; Africa, C.W.J. Measuring Streptococcus mutans, Streptococcus sanguinis and Candida albicans biofilm formation using a real-time impedance-based system. J. Microbiol. Methods 2020, 169. [CrossRef]

81. Diaz, P.I.; Valm, A.M. Microbial Interactions in Oral Communities Mediate Emergent Biofilm Properties. J. Dent. Res. 2020, 99, 18-25. [CrossRef]

82. Sztukowska, M.N.; Dutton, L.C.; Delaney, C.; Ramsdale, M.; Ramage, G.; Jenkinson, H.F.; Nobbs, A.H.; Lamont, R.J. Community development between Porphyromonas gingivalis and Candida albicans mediated by inIJ and Als3. MBio 2018, 9. [CrossRef]

83. Bartnicka, D.; Gonzalez-Gonzalez, M.; Sykut, J.; Koziel, J.; Ciaston, I.; Adamowicz, K.; Bras, G.; Zawrotniak, M.; KarkowskaKuleta, J.; Satala, D.; et al. Candida albicans shields the periodontal killer porphyromonas gingivalis from recognition by the host immune system and supports the bacterial infection of gingival tissue. Int. J. Mol. Sci. 2020, 21, 1984. [CrossRef]

84. Centers for Disease Control and Prevention Candida Infections of the Mouth, Throat, and Esophagus. Available online: https: / / www.cdc.gov/fungal/diseases/candidiasis/thrush/index.html (accessed on 4 January 2021).

85. Faith, J.J.; Guruge, J.L.; Charbonneau, M.; Subramanian, S.; Seedorf, H.; Goodman, A.L.; Clemente, J.C.; Knight, R.; Heath, A.C.; Leibel, R.L.; et al. The long-term stability of the human gut microbiota. Science 2013, 341, 1237439. [CrossRef]

86. Sekirov, I.; Russell, S.L.; Caetano, M.; Antunes, L.; Finlay, B.B. Gut microbiota in health and disease. Physiol. Rev. 2010, 90, 859-904. [CrossRef]

87. Jeziorek, M.; Frej-Mądrzak, M.; Choroszy-Król, I. The influence of diet on gastrointestinal Candida spp. colonization and the susceptibility of Candida spp. to antifungal drugs. Rocz. Panstw. Zakl. Hig. 2019, 70, 195-200. [CrossRef]

88. Mishra, A.A.; Koh, A.Y. Adaptation of Candida albicans During Gastrointestinal Tract Colonization. Curr. Clin. Microbiol. Rep. 2018, 5, 165-172. [CrossRef]

89. Tong, Y.; Tang, J. Candida albicans infection and intestinal immunity. Microbiol. Res. 2017, 198, 27-35. [CrossRef]

90. Zhu, W.; Filler, S.G. Interactions of Candida albicans with epithelial cells. Cell. Microbiol. 2010, 12, 273-282. [CrossRef]

91. Allert, S.; Förster, T.M.; Svensson, C.M.; Richardson, J.P.; Pawlik, T.; Hebecker, B.; Rudolphi, S.; Juraschitz, M.; Schaller, M.; Blagojevic, M.; et al. Candida albicans-induced epithelial damage mediates translocation through intestinal barriers. MBio 2018, 9. [CrossRef]

92. Robertson, K.D.; Nagra, N.; Mehta, D. Esophageal Candidiasis. StatPearls 2013, 1, 64-65. [CrossRef]

93. Mohamed, A.A.; Lu, X.L.; Mounmin, F.A. Diagnosis and Treatment of Esophageal Candidiasis: Current Updates. Can. J. Gastroenterol. Hepatol. 2019, 2019. [CrossRef]

94. Rosołowski, M.; Kierzkiewicz, M. Etiology, diagnosis and treatment of infectious esophagitis. Prz. Gastroenterol. 2013, 8, 333-337. [CrossRef]

95. Alsomali, M.I.; Arnold, M.A.; Frankel, W.L.; Graham, R.P.; Hart, P.A.; Lam-Himlin, D.M.; Naini, B.V.; Voltaggio, L.; Arnold, C.A. Challenges to "classic" esophageal candidiasis: Looks are usually deceiving. Am. J. Clin. Pathol. 2017, 147, 33-42. [CrossRef] 
96. Hoversten, P.; Otaki, F.; Katzka, D.A. Course of Esophageal Candidiasis and Outcomes of Patients at a Single Center. Clin. Gastroenterol. Hepatol. 2019, 17, 200-202.e1. [CrossRef]

97. Mushi, M.F.; Ngeta, N.; Mirambo, M.M.; Mshana, S.E. Predictors of esophageal candidiasis among patients attending endoscopy unit in a tertiary hospital, Tanzania: A retrospective cross-sectional study. Afr. Health Sci. 2018, 18, 66-71. [CrossRef]

98. Hoversten, P.; Kamboj, A.K.; Katzka, D.A. Infections of the esophagus: An update on risk factors, diagnosis, and management. Dis. Esophagus 2018, 31. [CrossRef]

99. Castelo Branco, S.; Ferreira, A.T.; Saraiva, S.; Silva, M.J.; Garcia, T. Fungal Gastroduodenitis. Eur. J. Case Rep. Intern. Med. 2017, 2. [CrossRef]

100. Stamatiades, G.A.; Ioannou, P.; Petrikkos, G.; Tsioutis, C. Fungal infections in patients with inflammatory bowel disease: A systematic review. Mycoses 2018, 61, 366-376. [CrossRef]

101. Moyes, D.L.; Richardson, J.P.; Naglik, J.R. Candida albicans-epithelial interactions and pathogenicity mechanisms: Scratching the surface. Virulence 2015, 6, 338-346. [CrossRef]

102. Naglik, J.R.; König, A.; Hube, B.; Gaffen, S.L. Candida albicans-epithelial interactions and induction of mucosal innate immunity. Curr. Opin. Microbiol. 2017, 40, 104-112. [CrossRef]

103. Richardson, J.P.; Ho, J.; Naglik, J.R. Candida-epithelial interactions. J. Fungi 2018, 4, 22. [CrossRef]

104. Gil-Bona, A.; Amador-García, A.; Gil, C.; Monteoliva, L. The external face of Candida albicans: A proteomic view of the cell surface and the extracellular environment. J. Proteom. 2018, 180, 70-79. [CrossRef]

105. Pappas, P.G.; Kauffman, C.A.; Andes, D.R.; Clancy, C.J.; Marr, K.A.; Ostrosky-Zeichner, L.; Reboli, A.C.; Schuster, M.G.; Vazquez, J.A.; Walsh, T.J.; et al. Clinical Practice Guideline for the Management of Candidiasis: 2016 Update by the Infectious Diseases Society of America. Clin. Infect. Dis. 2015, 62, e1-e50. [CrossRef]

106. Metin, A.; Dilek, N.; Bilgili, S.G. Recurrent candidal intertrigo: Challenges and solutions. Clin. Cosmet. Investig. Dermatol. 2018, 11, 175-185. [CrossRef]

107. Leggit, J.C. Acute and Chronic Paronychia. Am. Fam. Physician 2017, 96, 44-51.

108. Schlager, E.; Ashack, K.; Khachemoune, A. Erosio interdigitalis blastomycetica: A review of interdigital candidiasis. Dermatol. Online J. 2018, 24, 13030.

109. Spinillo, A.; Pizzoli, G.; Colonna, L.; Nicola, S.; De Seta, F.; Guaschino, S. Epidemiologic characteristics of women with idiopathic recurrent vulvovaginal candidiasis. Obs. Gynecol. 1993, 5, 721-727. [CrossRef]

110. Swamiappan, M. Anogenital pruritus-An overview. J. Clin. Diagn. Res. 2016, 10, WE01-WE03. [CrossRef]

111. Visscher, M.O.; Adam, R.; Brink, S.; Odio, M. Newborn infant skin: Physiology, development, and care. Clin. Dermatol. 2015, 33, 271-280. [CrossRef]

112. Darmstadt, G.L.; Dinulos, J.G.; Miller, Z. Congenital cutaneous candidiasis: Clinical presentation, pathogenesis, and management guidelines. Pediatrics 2000, 105, 438-444. [CrossRef]

113. Greenberg, R.G.; Benjamin, D.K. Neonatal candidiasis: Diagnosis, prevention, and treatment. J. Infect. 2014, 69, S19-S22. [CrossRef]

114. Grimbacher, B.; Holland, S.M.; Gallin, J.I.; Greenberg, F.; Hill, S.C.; Malech, H.L.; Miller, J.A.; O'Connell, A.C.; Dent, B.; Puck, J.M. Hyper-IgE syndrome with recurrent infections-An autosomal dominant multisystem disorder. N. Engl. J. Med. 1999, 340, 692-702. [CrossRef]

115. Mogensen, T.H. Primary Immunodeficiencies with Elevated IgE. Int. Rev. Immunol. 2016, 35, 39-56. [CrossRef]

116. Milner, J.D.; Brenchley, J.M.; Laurence, A.; Freeman, A.F.; Hill, B.J.; Elias, K.M.; Kanno, Y.; Spalding, C.; Elloumi, H.Z.; Paulson, M.L.; et al. Impaired TH17 cell differentiation in subjects with autosomal dominant hyper-IgE syndrome. Nature 2008, 452, 773-776. [CrossRef] [PubMed]

117. Wang, Y.C.; Tsai, I.C.; Lin, C.; Hsieh, W.P.; Lan, C.Y.; Chuang, Y.J.; Chen, B. Sen Essential functional modules for pathogenic and defensive mechanisms in candida albicans infections. Biomed. Res. Int. 2014, 2014, 136130-136130. [CrossRef] [PubMed]

118. de Leon, E.M.; Jacober, S.J.; Sobel, J.D.; Foxman, B. Prevalence and risk factors for vaginal Candida colonization in women with type 1 and type 2 diabetes. BMC Infect. Dis. 2002, 2, 1. [CrossRef] [PubMed]

119. Dorko, E.; Baranová, Z.; Jenča, A.; Kizek, P.; Pilipčinec, E.; Tkáčiková, L. Diabetes mellitus and candidiases. Folia Microbiol. 2005, 50, 255-261. [CrossRef] [PubMed]

120. Dicle, O.; Parmaksizoglu, B.; Gurkan, A.; Tuncer, M.; Demirbas, A.; Yilmaz, E. Skin infections in 401 renal transplant recipients in southern Turkey-PubMed. Exp. Clin. Transpl. 2009, 7, 133-136.

121. Bassetti, M.; Righi, E.; Costa, A.; Fasce, R.; Molinari, M.P.; Rosso, R.; Pallavicini, F.B.; Viscoli, C. Epidemiological trends in nosocomial candidemia in intensive care. BMC Infect. Dis. 2006, 6, 21. [CrossRef] [PubMed]

122. Xu, J.; Schwartz, K.; Bartoces, M.; Monsur, J.; Severson, R.K.; Sobel, J.D. Effect of antibiotics on vulvovaginal candidiasis: A metronet study. J. Am. Board Fam. Med. 2008, 21, 261-268. [CrossRef]

123. Seelig, M.S. The role of antibiotics in the pathogenesis of Candida infections. Am. J. Med. 1966, 40, 887-917. [CrossRef]

124. Baker, K.F.; Isaacs, J.D. Novel therapies for immune-mediated inflammatory diseases: What can we learn from their use in rheumatoid arthritis, spondyloarthritis, systemic lupus erythematosus, psoriasis, Crohn's disease and ulcerative colitis? Ann. Rheum. Dis. 2018, 77, 175-187. [CrossRef]

125. Kuwabara, T.; Ishikawa, F.; Kondo, M.; Kakiuchi, T. The Role of IL-17 and Related Cytokines in Inflammatory Autoimmune Diseases. Mediat. Inflamm. 2017, 2017. [CrossRef] 
126. Beringer, A.; Noack, M.; Miossec, P. IL-17 in Chronic Inflammation: From Discovery to Targeting. Trends Mol. Med. 2016, 22, 230-241. [CrossRef] [PubMed]

127. Conti, H.R.; Gaffen, S.L. IL-17-Mediated Immunity to the Opportunistic Fungal Pathogen Candida albicans. J. Immunol. 2015, 195, 780-788. [CrossRef] [PubMed]

128. Lesher, J. Oral therapy of common superficial fungal infections of the skin. J. Am. Acad. Dermatol. 1999, 40, S31-S34. [CrossRef]

129. Costa, C.; Dias, P.J.; Sá-Correia, I.; Teixeira, M.C. MFS multidrug transporters in pathogenic fungi: Do they have real clinical impact? Front. Physiol. 2014, 5, 197. [CrossRef]

130. Bhattacharya, S.; Sae-Tia, S.; Fries, B.C. Candidiasis and mechanisms of antifungal resistance. Antibiotics 2020, 9, 312. [CrossRef]

131. Choukri, F.; Benderdouche, M.; Sednaoui, P. In vitro susceptibility profile of 200 recent clinical isolates of Candida spp. to topical antifungal treatments of vulvovaginal candidiasis, the imidazoles and nystatin agents. J. Mycol. Med. 2014, 24, 303-307. [CrossRef]

132. Sonthalia, S.; Agrawal, M.; Sehgal, V. Topical ciclopirox olamine 1\%: Revisiting a unique antifungal. Indian Dermatol. Online J. 2019, 10, 481. [CrossRef]

133. Abrams, B.; Hanel, H.; Hoehler, T. Ciclopirox olamine: A hydroxypyridine antifungal agent. Clin. Dermatol. 1991, 9 , 471-477. [CrossRef]

134. Jandourek, A.; Brown, P.; Vazquez, J.A. Community-acquired fungemia due to a multiple-azole-resistant strain of Candida tropicalis. Clin. Infect. Dis. 1999, 29, 1583-1584. [CrossRef]

135. Vazquez, J.A.; Sobel, J.D. Anidulafungin: A novel echinocandin. Clin. Infect. Dis. 2006, 43, 215-222. [CrossRef]

136. European Medicines Agency. Suspension of Marketing Authorisations for Oral Ketoconazole Benefit of Oral Ketoconazole Does Not Outweigh Risk of Liver Injury in Fungal Infections on 25 July 2013, the European Medicines Agency's Committee on Medicinal Products for Human Use; European Medicines Agency: London, UK, 2013.

137. Gupta, A. Systemic antifungal agents. In Comprehensive Dermatologic Drug Therapy; Wolverton, S., Ed.; Saunder: Philadelphia, PA, USA, 2007; pp. 101-112.

138. Talapko, J.; Matijević, T.; Juzbašić, M.; Antolović-Požgain, A.; Škrlec, I. Antibacterial Activity of Silver and Its Application in Dentistry, Cardiology and Dermatology. Microorganisms 2020, 8, 1400. [CrossRef] [PubMed]

139. Hassan, A.; Mansour, K.; Mahmoud, H. Biosynthesis of silver nanoparticles(Ag-Nps) (a model of metals) by Candida albicans and its antifungal activity on Some fungal pathogens (Trichophyton mentagrophytes and Candida albicans). N. Y. Sci. J. 2013, $6,27-34$.

140. Choi, J.S.; Lee, J.W.; Shin, U.C.; Lee, M.W.; Kim, D.J.; Kim, S.W. Inhibitory activity of silver nanoparticles synthesized using lycopersicon esculentum against biofilm formation in candida species. Nanomaterials 2019, 9, 1512. [CrossRef] [PubMed]

141. Pappas, P.G.; Lionakis, M.S.; Arendrup, M.C.; Ostrosky-Zeichner, L.; Kullberg, B.J. Invasive candidiasis. Nat. Rev. Dis. Prim. 2018, 4, 1-20. [CrossRef] [PubMed]

142. Jabra-Rizk, M.A.; Kong, E.F.; Tsui, C.; Nguyen, M.H.; Clancy, C.J.; Fidel, P.L.; Noverr, M. Candida albicans pathogenesis: Fitting within the host-microbe damage response framework. Infect. Immun. 2016, 84, 2724-2739. [CrossRef] [PubMed]

143. Rosati, D.; Bruno, M.; Jaeger, M.; Ten Oever, J.; Netea, M.G. Recurrent Vulvovaginal Candidiasis: An Immunological Perspective. Microorganisms 2020, 8, 144. [CrossRef]

144. Gonzalez-Lara, M.F.; Ostrosky-Zeichner, L. Invasive Candidiasis. Semin. Respir. Crit. Care Med. 2020, 41, 3-12. [CrossRef]

145. Yapar, N. Epidemiology and risk factors for invasive candidiasis. Ther. Clin. Risk Manag. 2014, 10, 95-105. [CrossRef]

146. Kauffman, C.A.; Vazquez, J.A.; Sobel, J.D.; Gallis, H.A.; McKinsey, D.S.; Karchmer, A.W.; Sugar, A.M.; Sharkey, P.K.; Wise, G.J.; Mangi, R.; et al. Prospective multicenter surveillance study of funguria in hospitalized patients. Clin. Infect. Dis. 2000, 30, 14-18. [CrossRef]

147. Ang, B.S.P.; Telenti, A.; King, B.; Steckelberg, J.M.; Wilson, W.R. Candidemia from a urinary tract source: Microbiological aspects and clinical significance. Clin. Infect. Dis. 1993, 17, 662-666. [CrossRef]

148. Haron, E.; Vartivarian, S.; Anaissie, E.; Dekmezian, R.; Bodey, G. Primary Candida pneumonia. Experience at a large cancer center and review of the literature. Medicine 1993, 72, 137-142. [CrossRef] [PubMed]

149. Kontoyiannis, D.P.; Reddy, B.T.; Torres, H.A.; Luna, M.; Lewis, R.E.; Tarrand, J.; Bodey, G.P.; Raad, I.I. Pulmonary candidiasis in patients with cancer: An autopsy study. Clin. Infect. Dis. 2002, 34, 400-403. [CrossRef] [PubMed]

150. Barton, M.; Shen, A.; O’Brien, K.; Robinson, J.L.; Davies, H.D.; Simpson, K.; Asztalos, E.; Langley, J.; Le Saux, N.; Sauve, R.; et al. Early-onset invasive candidiasis in extremely low birth weight infants: Perinatal acquisition predicts poor outcome. Clin. Infect. Dis. 2017, 64, 921-927. [CrossRef] [PubMed]

151. Schnabel, R.M.; Linssen, C.F.; Guion, N.; Van Mook, W.N.; Bergmans, D.C. Candida pneumonia in intensive care unit? Open Forum Infect. Dis. 2014, 1. [CrossRef] [PubMed]

152. Johnson, M.D.; Perfect, J.R. Fungal infections of the bones and joints. Curr. Infect. Dis. Rep. 2001, 3, 450-460. [CrossRef] [PubMed]

153. Miller, D.J.; Mejicano, G.C. Vertebral osteomyelitis due to Candida species: Case report and literature review. Clin. Infect. Dis. 2001, 33, 523-530. [CrossRef] [PubMed]

154. Gamaletsou, M.N.; Kontoyiannis, D.P.; Sipsas, N.V.; Moriyama, B.; Alexander, E.; Roilides, E.; Brause, B.; Walsh, T.J. Candida osteomyelitis: Analysis of 207 pediatric and adult cases (1970-2011). Clin. Infect. Dis. 2012, 55, 1338-1351. [CrossRef]

155. Shoham, S.; Nucci, M.; Walsh, T.J. Mucocutaneous and Deeply Invasive Candidiasis. In Tropical Infectious Diseases; Guerrant, R.L., Walker, D.H., Weller, P.F., Eds.; Elsevier Inc.: Boston, MA, USA, 2011; pp. 589-596. ISBN 9780702039355. 
156. Weitkamp, J.H.; Nania, J.J. Infectious Diseases. In Neonatal Neurology; Fenichel, G.M., Ed.; Elsevier Inc.: Boston, MA, USA, 2007; pp. 109-141. ISBN 9780443067242.

157. Mamtani, S.S.; Aljanabi, N.M.; Gupta Rauniyar, R.P.; Acharya, A.; Malik, B.H. Candida Endocarditis: A Review of the Pathogenesis, Morphology, Risk Factors, and Management of an Emerging and Serious Condition. Cureus 2020, 12. [CrossRef]

158. Baddley, J.W.; Benjamin, D.K.; Patel, M.; Miró, J.; Athan, E.; Barsic, B.; Bouza, E.; Clara, L.; Elliott, T.; Kanafani, Z.; et al. Candida infective endocarditis. Eur. J. Clin. Microbiol. Infect. Dis. 2008, 27, 519-529. [CrossRef]

159. Author, C.; Shokohi, T.; Reza Aghili, S.; Ali Boroumand, M.; Hashemi Fesharaki, S.; Salmanian, B. Intravenous Catheter-Associated Candidemia due to Candida membranaefaciens: The First Iranian Case. J. Tehran Univ. Heart Center 2015, 10, $101-105$.

160. Logan, C.; Martin-Loeches, I.; Bicanic, T. Invasive candidiasis in critical care: Challenges and future directions. Intensive Care Med. 2020, 46, 2001-2014. [CrossRef] [PubMed]

161. Calandra, T.; Roberts, J.A.; Antonelli, M.; Bassetti, M.; Vincent, J.L. Diagnosis and management of invasive candidiasis in the ICU: An updated approach to an old enemy. Crit. Care 2016, 20, 125. [CrossRef] [PubMed]

162. Beardsley, J.; Halliday, C.L.; Chen, S.C.A.; Sorrell, T.C. Responding to the emergence of antifungal drug resistance: Perspectives from the bench and the bedside. Future Microbiol. 2018, 13, 1175-1191. [CrossRef] [PubMed]

163. Wiederhold, N.P. Antifungal resistance: Current trends and future strategies to combat. Infect. Drug Resist. 2017, 10, 249-259. [CrossRef] [PubMed]

164. Costa-de-Oliveira, S.; Rodrigues, A.G. Candida albicans Antifungal Resistance and Tolerance in Bloodstream Infections: The Triad Yeast-Host-Antifungal. Microorganisms 2020, 8, 154. [CrossRef] [PubMed]

165. Siddharthan, T.; Karakousis, P.C.; Checkley, W. Empirical antifungal therapy in critically ill patients with sepsis. JAMA J. Am. Med. Assoc. 2016, 316, 1549-1550. [CrossRef] [PubMed]

166. Eschenauer, G.A.; Kwak, E.J.; Humar, A.; Potoski, B.A.; Clarke, L.G.; Shields, R.K.; Abdel-Massih, R.; Silveira, F.P.; Vergidis, P.; Clancy, C.J.; et al. Targeted Versus Universal Antifungal Prophylaxis Among Liver Transplant Recipients. Am. J. Transplant. 2015, 15, 180-189. [CrossRef]

167. Hsu, J.F.; Lai, M.Y.; Lee, C.W.; Chu, S.M.; Wu, I.H.; Huang, H.R.; Lee, I.T.; Chiang, M.C.; Fu, R.H.; Tsai, M.H. Comparison of the incidence, clinical features and outcomes of invasive candidiasis in children and neonates. BMC Infect. Dis. 2018, 18, 194. [CrossRef]

168. Badiee, P. Evaluation of human body fluids for the diagnosis of fungal infections. Biomed. Res. Int. 2013, 2013. [CrossRef]

169. Cobo, F.; Rodríguez-Granger, J.; Sampedro, A.; Aliaga-Martínez, L.; Navarro-Marí, J.M. Candida Prosthetic Joint Infection. A Review of Treatment Methods. J. Bone Jt. Infect. 2017, 2, 114-121. [CrossRef]

170. Pfaller, M.A.; Castanheira, M. Nosocomial candidiasis: Antifungal stewardship and the importance of rapid diagnosis. Med. Mycol. 2016, 54, 1-22. [CrossRef] [PubMed]

171. Tissot, F.; Agrawal, S.; Pagano, L.; Petrikkos, G.; Groll, A.H.; Skiada, A.; Lass-Flörl, C.; Calandra, T.; Viscoli, C.; Herbrecht, R. ECIL-6 guidelines for the treatment of invasive candidiasis, aspergillosis and mucormycosis in leukemia and hematopoietic stem cell transplant patients. Haematologica 2017, 102, 433-444. [CrossRef]

172. Bow, E.J.; Evans, G.; Fuller, J.; Laverdière, M.; Rotstein, C.; Rennie, R.; Shafran, S.D.; Sheppard, D.; Carle, S.; Phillips, P.; et al. Canadian clinical practice guidelines for invasive candidiasis in adults. Can. J. Infect. Dis. Med. Microbiol. $2010,21$. [CrossRef] [PubMed]

173. Wang, Y.; McGuire, T.M.; Hollingworth, S.A.; Dong, Y.; Van Driel, M.L. Antifungal agents for invasive candidiasis in nonneutropenic critically ill adults: What do the guidelines recommend? Int. J. Infect. Dis. 2019, 89, 137-145. [CrossRef] [PubMed]

174. Patterson, T.F.; Thompson, G.R.; Denning, D.W.; Fishman, J.A.; Hadley, S.; Herbrecht, R.; Kontoyiannis, D.P.; Marr, K.A.; Morrison, V.A.; Nguyen, M.H.; et al. Practice guidelines for the diagnosis and management of aspergillosis: 2016 update by the infectious diseases society of America. Clin. Infect. Dis. 2016, 63, e1-e60. [CrossRef] [PubMed]

175. Johnson, M.D.; Perfect, J.R. Use of antifungal combination therapy: Agents, order, and timing. Curr. Fungal Infect. Rep. 2010, 4, 87-95. [CrossRef] 